\title{
Evaluation of Brown Rot Resistance and its Relation to Enzymatic Browning in Clingstone Peach Germplasm
}

\author{
T.M. Gradziel and Dechun Wang ${ }^{1}$ \\ Department of Pomology, University of California, Davis, CA 95616 \\ Additional index words. Prunus persica, phenolic compounds, polyphenol oxidase, bruising, Monilinia fructicola
}

\begin{abstract}
Rate of brown rot lesion development following inoculation with Monilinia fructicola (Wint.) honey varied within clingstone peach (Prunus persica (L.) Batsch) germplasm evaluated in 1990 and 1991 . High levels of resistance were identified in selections derived from the Brazilian clingstone peach cultivar Bolinha. Resistance appeared to be limited to the epidermal tissue. No relation was detected between brown rot resistance and concentration of phenolic compounds or polyphenol oxidase activity in the susceptible California germplasm. An inverse relation was observed between disease severity and rating for phenolic-related discoloration when 'Bolinha' derived selections were analyzed. A moderate positive correlation was observed for all germplasm tested between genotype means for phenolic content and enzymatic browning. Any causal relationship, if it exists, between phenolic content and brown rot resistance is obscured by an array of physical and chemical changes in the maturing fruit.
\end{abstract}

Brown Rot, caused by Monilinia fructicola, is the major cause of harvest and postharvest losses of peaches and nectarines in California (Ogawa et al., 1985). The processing clingstone peach is highly susceptible. The harvesting of processing peaches at the full-ripe rather than the more resistant mature-green stage further contributes to disease incidence. Phenolic metabolism has been implicated in fungal resistance for a range of horticultural crops (Manibhushanrao et al., 1988; Sztejnberg et al., 1983). Amounts of phenolic compounds and polyphenol oxidase (PPO) enzyme activity, which catalyzes polyphenol oxidation, also determine enzymatic browning potential in fresh fruits (Kader, 1980; Lee et al., 1990; Van Buren, 1970). Phenolic compounds are normally found within the cell vacuole, separated from the PPO, which is confined to the cytoplasm. With cell lysis, either through puncture or impact damage, polyphenolic compounds are exposed to PPO, resulting in their oxidation to quinones. Quinones are highly unstable and rapidly polymerize to form brown products. Strong selection pressures have been applied against enzymatic browning in processing peach cultivar development programs due to the undesirable consequences on fruit color (Kader, 1980; Kader and Chordas, 1984; Werner and Ballington, 1982). While the effect of PPO levels on disease resistance remains unclear (Gupta and Kaul, 1987; Manibhushanrao et al., 1988), proposed roles for plant phenolics include protection of damaged tissue (Aist, 1983; Barkhausen, 1978; Lakshminarayana et al., 1987; Mace, 1963; Reeve, 1959), inhibition of fungal wall degrading enzymes (Byrde and Willets, 1977; Hall, 1971) and as substrates for antifungal compounds elicited at infection (Friend, 1985; Manibhushanrao et al., 1988; Byrde and Willets, 1977).

Feliciano et al. (1987) have identified relatively high levels of brown rot resistance in the Brazilian clingstone peach cultivar Bolinha. The fruit epidermis, which possesses a thicker cuticle, more compact cell type, and fewer trichomes than that of other cultivars, has been identified as a probable site of resistance (Adaskaveg

Received for publication 26 May 1992. Accepted for publication 5 Dec. 1992. The cost of publishing this paper was defrayed in part by the payment of page charges. Under postal regulations, this paper therefore must be hereby marked advertisement solely to indicate this fact.

'Current address: Dept. of Horticulture, Michigan State Univ., East Lansing, MI 48824 . et al., 1991). Poor fruit color combined with excessive preharvest drop, however, have deterred commercialization of 'Bolinha'. Open-pollinated seedlings (Bolinha-OPs) have been selected for brown rot resistance (Adaskeveg et al., 1989), and are now being incorporated into the California cultivar improvement program.

The purpose of this research was to characterize the levels of brown rot resistance in available clingstone peach germplasm, and to assess possible associations with enzymatic browning potential.

\section{Materials and Methods}

Fruit of clingstone peach genotypes, including cultivars, advanced selections, Bolinha-OPs, and seedling lines resulting from controlled hybridizations of the Bolinha-OP selections to California adapted germplasm (Bolinha-OP-Hyb), were designated with a breeding line reference number and evaluated (Tables 1 and 2). Trees were grown in experimental orchards in Davis and Winters, Calif., under standard fertilizer and water regimes but without fungicide sprays. Fruit samples, representing the normal range of maturities harvested in commercial operations (based on skin color change from green to yellow), were hand harvested and transported to the laboratory in single-layer, cupped plastic trays to minimize fruit damage. Fruit were kept at $22 \mathrm{C}$ for at least $12 \mathrm{~h}$ to dissipate field heat.

In 1990, Benomyl sensitive cultures of M. fructicola were obtained from J.M. Ogawa, Dept. of Plant Pathology, Univ. of California, Davis. Conidial suspensions were produced by washing 5 to 7 day old PDA cultures with a $20-\mathrm{ml}$ sterile distilled water containing $0.01 \%$ Tween 20 as a wetting agent. Inoculum was filtered through four layers of sterile cheesecloth to minimize the presence of mycelial fragments and was adjusted to a concentration of $2 \times 10^{4}$ conidia per milliliter. Conidial suspension $(10 \mu \mathrm{l})$ was deposited on the fruit surface, previously determined to be free of visible injury by stereo microscope examination. Inoculated fruit was incubated for $72 \mathrm{~h}$ at 22 to $25 \mathrm{C}$ in darkness at $\approx 95 \%$ relative humidity $(\mathrm{RH})$. High humidity was maintained by placing fruit on plastic supports in plastic containers containing sterile cheesecloth soaked in sterile distilled water. At least 16 fruit per genotype were tested. An additional five fully ripe fruit of each line were tested for flesh resistance by directly inoculating an area of flesh wounded by removal of a 6-mm deep slice of epidermis and 
flesh from the most mature fruit cheek. Lesion diameters were recorded $72 \mathrm{~h}$ after inoculation. Phenolic levels were estimated by the Nitroso rapid assay developed by Kader and Chordas (1984).

In 1991, fruit epidermis (ground) color of a $3 \mathrm{~cm}$ diameter disk centered on the area of the fruit to be inoculated and biochemically tested was measured using a Colormet Spectrophotometer (Agtron, Reno, Nev.). The spectrophotometer was calibrated to a white porcelain reference plate $\left(\mathrm{L}^{*}=94.5, \mathrm{a}^{*}=-1.0, \mathrm{~b}^{*}=0.0\right)$. Areas of red pigmentation (blush) were avoided. Light reflectance from 400 to $700 \mathrm{~nm}$ at $10 \mathrm{~nm}$ intervals was recorded for each fruit tested. CIE 1976 L*a*b* color values were computed from reflected spectrum data using standard formulas (Hunt, 1987), with hue angle calculated as the arctangent of ( $\left.\mathrm{b}^{*} / \mathrm{a}^{*}\right)$. Hue angle, which provides an approximately uniform measure of ground color hue from $180^{\circ}$ (green) to $0^{\circ}$ (red) (Little, 1975), was employed as amaturity index as previously reported (Delwiche and Baumgardner, 1983; Meredith et al., 1989; Robertson et al., 1991). At least 30 fruit per line were inoculated at the site of color measurement, and lesion diameter was recorded after 48 and $72 \mathrm{~h}$.

At least 20 fruit per line were bruised by dropping a $2.5 \mathrm{~cm}$ diameter $(64.2 \mathrm{~g})$ steel ball from a $30 \mathrm{~cm}$ height onto the more mature peach fruit cheek. The impact area was marked with black indelible ink. The fruit were then placed in cupped plastic trays and kept at $22 \mathrm{C}$ for $24 \mathrm{~h}$. At that time, flesh bruise color at a $6 \mathrm{~mm}$ depth was rated, using a standardized color chart developed according to the following scale: $1=$ no bruise visible, $2=$ translucent area with no discoloration, 3 = pale tan bruise, $4=$ light brown bruise, $5=$ brown bruise.

Flesh phenolics were estimated using the Nitroso test (Kader and Chordas, 1984). In addition to flesh, the epidermis was tested. The surface fuzz and some of the cuticle were first removed by lightly buffing the test site with multiple layers of cheesecloth for a period of $5 \mathrm{sec}$ with a force of $\approx 0.34 \mathrm{~N}$ using a modified Vortex Genie mixer.
To assess PPO activity, fruit was sliced parallel to the suture to a depth of $6 \mathrm{~mm}$. One drop of freshly prepared $0.1 \mathrm{M}$ catechol solution was applied to the center of the 4 to $5 \mathrm{~cm}$ disk of exposed flesh. After 6 min the intensity of the resulting brown discoloration was scored relative to the standardized chart of Kader and Chordas (1984). PPO activity was similarly estimated for the fruit epidermis after first buffing the test surface as described above.

Data were analyzed by the General Linear Models procedure of the Statistical Analysis System (SAS) (SAS Institute, 1985). Lines were ranked within categories using Duncan's Multiple Range Test.

\section{Results}

Considerable differences between lines were observed in 1990 for the mean lesion diameter $72 \mathrm{~h}$ after inoculation of unwounded fruit with $M$. fructicola (Table 1). No disease development was apparent on unwounded Bolinha-OP selections under test conditions, with only limited lesion development observed on BolinhaOP-Hyb fruit (lines with Hyb-prefix in tables). Of the California germplasm tested, only the cultivars 'Dr. Davis', 'Ross' and the advanced breeding line UC18,8-23 exhibited notable resistance. No relationship was observed between phenolic rating and rot lesion diameter within the Californian germplasm. Lesion diameter in the 'Bolinha' derived material, however, was inversely related to phenolics. Bolinha-OP lines showed high phenolic levels with most individual fruit ratings being at or beyond the maximum score of 5. Two cultivars, 'Kakamas' and 'Late Spanish Cling', also displayed high phenolic ratings though without appreciable brown rot resistance. When wounded flesh tissue was inoculated, all lines tested produced lesions with diameter means $>30 \mathrm{~mm}$ at $72 \mathrm{~h}$ after inoculation.

Similar results were obtained in 1991 evaluations (Table 2 and Fig. 1). Lesion diameter means were uniformly higher than in

Table 1. Comparison of sample means for rating for flesh phenolics at harvest and brown rot lesion diameter at $72 \mathrm{~h}$ after inoculation of unwounded fruit of clingstone peach lines evaluated in $1990 .^{\mathrm{z}}$

\begin{tabular}{clcc}
\hline $\begin{array}{c}\text { Reference } \\
(\text { no. })\end{array}$ & $\begin{array}{c}\text { Cultivar or } \\
\text { breeding line }\end{array}$ & $\begin{array}{c}\text { Lesion diam } \\
(\mathrm{mm})\end{array}$ & $\begin{array}{c}\text { Phenolics } \\
(\text { rating })\end{array}$ \\
\hline 5 & BOLINHA-OP-7 & $0 \mathrm{a}$ & $5.0 \mathrm{a}$ \\
6 & BOLINHA-OP-4 & $0 \mathrm{a}$ & $4.6 \mathrm{~b}$ \\
2 & BOLINHA-OP-3 & $0 \mathrm{a}$ & $4.4 \mathrm{bc}$ \\
27 & Hyb-88611 & $1 \mathrm{a}$ & $3.7 \mathrm{de}$ \\
28 & Hyb-88614 & $3 \mathrm{ab}$ & $4.0 \mathrm{~cd}$ \\
36 & Hyb-87331 & $10 \mathrm{bc}$ & $3.1 \mathrm{f}$ \\
9 & Dr. Davis & $10 \mathrm{bc}$ & $2.3 \mathrm{gh}$ \\
10 & Ross & $10 \mathrm{bc}$ & $1.8 \mathrm{i}$ \\
29 & Hyb-88275 & $13 \mathrm{c}$ & $2.1 \mathrm{ghi}$ \\
8 & UC18, 8-23 & $14 \mathrm{c}$ & $4.5 \mathrm{~b}$ \\
12 & Andross & $27 \mathrm{~d}$ & $4.0 \mathrm{~cd}$ \\
30 & Hesse & $29 \mathrm{de}$ & $3.5 \mathrm{e}$ \\
31 & Klamt & $31 \mathrm{de}$ & $4.0 \mathrm{~cd}$ \\
19 & Carson & $32 \mathrm{de}$ & $2.4 \mathrm{~g}$ \\
32 & Late Spanish Cling & $33 \mathrm{def}$ & $5.0 \mathrm{a}$ \\
33 & Kakamas & $34 \mathrm{def}$ & $4.8 \mathrm{ab}$ \\
34 & Dixon & $37 \mathrm{~d}-\mathrm{g}$ & $2.9 \mathrm{f}$ \\
26 & Peak & $37 \mathrm{efg}$ & $3.0 \mathrm{f}$ \\
35 & Tufts & $41 \mathrm{fg}$ & $1.9 \mathrm{hi}$ \\
17 & Corona & $44 \mathrm{~g}$ & $3.1 \mathrm{f}$ \\
25 & Reigels & $44 \mathrm{~g}$ & $3.7 \mathrm{de}$
\end{tabular}

${ }^{\bar{z}}$ Mean separation within columns by Duncan's multiple range test, $P=0.05$. 
Table 2. Comparison of polyphenol oxidase activity (PPO), phenolic content, impact bruising mean scores, and brown rot mean lesion diameter for clingstone peach lines tested in $1991 .^{\mathrm{z}}$

\begin{tabular}{|c|c|c|c|c|c|c|c|c|}
\hline \multirow{2}{*}{$\begin{array}{c}\text { Reference } \\
\text { (no.) }\end{array}$} & \multirow{2}{*}{$\begin{array}{l}\text { Cultivar } \\
\text { or line }\end{array}$} & \multicolumn{2}{|c|}{ PPO rating } & \multicolumn{2}{|c|}{ Phenolic rating } & \multirow{2}{*}{$\begin{array}{l}\text { Bruise } \\
\text { Rating }\end{array}$} & \multicolumn{2}{|c|}{ Lesion diam (mm) } \\
\hline & & Skin & Flesh & Skin & Flesh & & $48 \mathrm{~h}$ & $72 \mathrm{~h}$ \\
\hline 1 & Hyb-891061 & $3.5 \mathrm{~b}-\mathrm{g}$ & $1.5 \mathrm{~g}-\mathrm{k}$ & $4.8 \mathrm{ab}$ & $4.6 \mathrm{a}-\mathrm{d}$ & $4.4 \mathrm{abc}$ & $0 \mathrm{a}$ & $2 \mathrm{a}$ \\
\hline 2 & Bolinha-OP-3 & $2.7 \mathrm{gh}$ & $2.8 \mathrm{abc}$ & $5.0 \mathrm{a}$ & $5.0 \mathrm{a}$ & $3.7 \mathrm{~b}-\mathrm{f}$ & $0 \mathrm{a}$ & $2 \mathrm{a}$ \\
\hline 3 & Hyb-891053 & $3.3 \mathrm{efg}$ & $1.2 \mathrm{i}-1$ & $4.7 \mathrm{a}-\mathrm{d}$ & $4.7 \mathrm{abc}$ & $4.4 \mathrm{abc}$ & $0 \mathrm{a}$ & $2 a$ \\
\hline 4 & Hyb-891044 & $2.5 \mathrm{hi}$ & $1.4 \mathrm{~g}-\mathrm{k}$ & $4.5 \mathrm{a}-\mathrm{e}$ & $4.8 \mathrm{ab}$ & $4.6 \mathrm{ab}$ & $0 \mathrm{a}$ & $2 \mathrm{a}$ \\
\hline 5 & Bolinha-OP-7 & $2.3 \mathrm{i}$ & $2.2 \mathrm{c}-\mathrm{g}$ & $5.0 \mathrm{a}$ & $5.0 \mathrm{a}$ & $3.4 \mathrm{c}-\mathrm{h}$ & $0 \mathrm{a}$ & $4 \mathrm{a}$ \\
\hline 6 & Bolinha-OP-4 & $2.9 \mathrm{fgh}$ & $1.9 \mathrm{~d}-\mathrm{j}$ & $4.9 \mathrm{ab}$ & $5.0 \mathrm{a}$ & $2.9 \mathrm{e}-\mathrm{j}$ & $1 \mathrm{a}$ & $4 a b$ \\
\hline 7 & Walgant & $3.0 \mathrm{fgh}$ & $0.8 \mathrm{kl}$ & $3.7 \mathrm{fgh}$ & $2.9 \mathrm{ij}$ & $1.9 \mathrm{jk}$ & $1 \mathrm{a}$ & $9 \mathrm{bc}$ \\
\hline 8 & UC18, 8-23 & $3.4 c-g$ & $2.1 \mathrm{c}-\mathrm{i}$ & $4.5 \mathrm{a}-\mathrm{e}$ & $4.5 \mathrm{a}-\mathrm{e}$ & $3.3 \mathrm{c}-\mathrm{h}$ & $1 \mathrm{a}$ & $11 \mathrm{~cd}$ \\
\hline 9 & Dr. Davis & $4.9 \mathrm{a}$ & $2.9 \mathrm{abc}$ & $4.0 \mathrm{e}-\mathrm{h}$ & $3.8 \mathrm{fgh}$ & $2.4 \mathrm{~g}-\mathrm{k}$ & $2 \mathrm{~b}$ & $11 \mathrm{cde}$ \\
\hline 10 & Ross & $4.1 \mathrm{~b}$ & $2.9 \mathrm{abc}$ & $3.3 \mathrm{~h}$ & $2.6 \mathrm{j}$ & $1.7 \mathrm{k}$ & $3 \mathrm{~b}$ & 13 cde \\
\hline 11 & Hyb-891047 & $3.4 c-g$ & $1.5 \mathrm{~g}-\mathrm{k}$ & $4.6 \mathrm{a}-\mathrm{e}$ & $4.8 \mathrm{ab}$ & $4.7 \mathrm{ab}$ & $4 b c$ & $16 \mathrm{def}$ \\
\hline 12 & Andross & $3.0 \mathrm{fgh}$ & $3.6 \mathrm{a}$ & $4.2 \mathrm{~b}-\mathrm{f}$ & $4: 8 \mathrm{ab}$ & $4.7 \mathrm{ab}$ & 4 cde & $17 \mathrm{fgh}$ \\
\hline 13 & Carolyn & $3.2 \mathrm{efg}$ & $1.7 \mathrm{e}-\mathrm{j}$ & $2.3 \mathrm{i}$ & $1.3 \mathrm{k}$ & $2.2 \mathrm{~h}-\mathrm{k}$ & $7 \mathrm{de}$ & 18 efg \\
\hline 14 & Sullivan-4 & $4.1 \mathrm{~b}$ & $2.7 \mathrm{bcd}$ & $4.6 \mathrm{a}-\mathrm{e}$ & $4.6 \mathrm{a}-\mathrm{d}$ & $3.8 \mathrm{~b}-\mathrm{f}$ & $5 \mathrm{bcd}$ & $19 \mathrm{fg}$ \\
\hline 15 & Hyb-8837 & $3.4 c-g$ & $1.3 \mathrm{~h}-1$ & $4.5 \mathrm{a}-\mathrm{e}$ & $5.0 \mathrm{a}$ & $4.0 \mathrm{a}-\mathrm{e}$ & $6 \mathrm{~b}-\mathrm{e}$ & 22 ghi \\
\hline 16 & Rizzi & $3.0 \mathrm{fgh}$ & $1.7 \mathrm{e}-\mathrm{k}$ & $2.1 \mathrm{i}$ & $2.5 \mathrm{j}$ & $2.4 \mathrm{~g}-\mathrm{k}$ & $7 \mathrm{de}$ & $23 \mathrm{ghi}$ \\
\hline 17 & Corona & $4.7 \mathrm{a}$ & $3.3 \mathrm{ab}$ & $4.7 \mathrm{abc}$ & $4.3 \mathrm{~b}-\mathrm{f}$ & $2.7 \mathrm{f}-\mathrm{k}$ & 7 efg & $25 \mathrm{hij}$ \\
\hline 18 & Hyb-88276 & $3.6 \mathrm{~b}-\mathrm{f}$ & $1.6 \mathrm{f}-\mathrm{k}$ & $4.6 \mathrm{a}-\mathrm{e}$ & $4.8 \mathrm{ab}$ & $4.3 \mathrm{a}-\mathrm{d}$ & $7 \mathrm{def}$ & $25 \mathrm{hij}$ \\
\hline 19 & Carson & $4.7 \mathrm{a}$ & $1.7 \mathrm{e}-\mathrm{k}$ & $4.3 \mathrm{a}-\mathrm{f}$ & $2.6 \mathrm{j}$ & $2.7 \mathrm{f}-\mathrm{k}$ & $10 \mathrm{hi}$ & $26 \mathrm{ijk}$ \\
\hline 20 & Halford & $3.3 \mathrm{~d}-\mathrm{g}$ & $1.2 \mathrm{jkl}$ & $4.1 \mathrm{c}-\mathrm{g}$ & $4.5 \mathrm{a}-\mathrm{e}$ & $3.1 \mathrm{e}-\mathrm{i}$ & $9 \mathrm{ghi}$ & $27 \mathrm{ijk}$ \\
\hline 21 & Monaco & $3.9 \mathrm{bcd}$ & $1.8 \mathrm{e}-\mathrm{j}$ & $4.2 \mathrm{~b}-\mathrm{f}$ & $4.1 \mathrm{c}-\mathrm{g}$ & $3.3 c-h$ & $9 \mathrm{f}-\mathrm{i}$ & $28 \mathrm{jk}$ \\
\hline 22 & Starn & $4.0 \mathrm{bc}$ & $2.2 \mathrm{c}-\mathrm{h}$ & $4.2 \mathrm{~b}-\mathrm{f}$ & $3.7 \mathrm{fgh}$ & $3.7 \mathrm{~b}-\mathrm{f}$ & $7 \mathrm{e}-\mathrm{h}$ & $28 \mathrm{jk}$ \\
\hline 23 & Andora & $4.1 \mathrm{~b}$ & $1.6 \mathrm{f}-\mathrm{k}$ & $2.7 \mathrm{i}$ & $1.7 \mathrm{k}$ & $2.1 \mathrm{ijk}$ & $11 \mathrm{i}$ & $31 \mathrm{jk}$ \\
\hline 24 & Everts & $3.7 \mathrm{~b}-\mathrm{e}$ & $2.4 \mathrm{c}-\mathrm{f}$ & $4.0 \mathrm{e}-\mathrm{h}$ & $3.9 \mathrm{e}-\mathrm{h}$ & $3.6 \mathrm{~b}-\mathrm{g}$ & $14 j$ & 381 \\
\hline 25 & Reigels & $3.7 \mathrm{~b}-\mathrm{e}$ & $2.2 \mathrm{c}-\mathrm{g}$ & $3.8 \mathrm{fgh}$ & $4.0 \mathrm{~d}-\mathrm{g}$ & $3.7 \mathrm{~b}-\mathrm{f}$ & $16 \mathrm{jk}$ & 391 \\
\hline 26 & Peak & $3.9 \mathrm{bcd}$ & $1.5 \mathrm{f}-\mathrm{k}$ & $3.4 \mathrm{~h}$ & $2.6 \mathrm{j}$ & $2.8 \mathrm{e}-\mathrm{k}$ & $17 \mathrm{k}$ & 391 \\
\hline
\end{tabular}

${ }^{\bar{z}}$ Mean separation within columns by Duncan's multiple range test, $P=0.05$.

1990, probably due to environmental and/or fungal isolate differences. Flesh phenolic rating mean scores and the relative rankings of lesion size and phenolics for those lines retested in 1991 were in good agreement with 1990 findings. An exception was mean lesion diameter in 'Corona', which approached the population median in 1991 as opposed to the near maximum score in 1990.

Lesion measurements were made at both 48 and $72 \mathrm{~h}$ in 1991 in an attempt to separate any flesh based resistance from that expressed in the epidermis. A strong linear relation without significant outliers $(\mathrm{y}=2.87 \mathrm{x}, r=0.97)$ was observed when 48 and $72 \mathrm{~h}$ fruit lesion measurements were compared.

While no overall relation was apparent between 1991 phenolic ratings and lesion diameter, the Bolinha-OP selections were again concentrated at the extremes, both in magnitude of rating for phenolics and lesion size (Fig. 2). Bolinha-OP-Hyb lines were also clustered in these regions. Bruise ratings for the Bolinha-OP selections were only moderately severe in spite of their often maximum flesh ratings for phenolics (Table 2 and Fig. 3). The Bolinha-OP-Hyb progeny, while showing somewhat lower though still high flesh ratings for phenolics, had the highest levels of bruise damage.

A moderately high correlation $(r=0.76)$ was observed between genotype means for flesh phenolics and the respective bruise rating (Fig. 3). A similar correlation $(r=0.67)$ has been reported by Lee et al. (1990) in a similar comparison between phenolic content and enzymatic browning in freestone peach.

Mean phenolic rating for the fruit epidermis was found to be similar in magnitude and well-correlated with flesh ratings in 1991 $(r=0.86)$. Exceptions were noted in a few lines including 'Walgant' a seedling of 'Kakamas', 'Ross', 'Carolyn', 'Carson', and 'Andora'.
Rating for fruit epidermis PPO was poorly correlated with flesh rating $(r=0.45)$. Notably less epidermis PPO activity was associated with the Bolinha-OP lines. Analysis of the epidermis PPO activity with ripening showed no appreciable change in either 'Bolinha-OP-7' or 'Corona' (Fig. 1) or in any of the other lines tested.

\section{Discussion}

A general fruit flesh susceptibility to brown rot of all genotypes tested is indicated by the similar high rates of lesion expansion in 1991, and the rapid infection of wounded fruit in 1990. An absence of flesh based resistance has been previously reported by Adaskaveg et al. $(1989 ; 1991)$ for clingstone peach. Resistance, while present in 'Bolinha' derived material, was limited to the epidermis. The consistency of high resistance with high phenolic activity in the epidermis and flesh of the Bolinha-OP's as well as their hybrids suggests these traits are heritable and linked. Low phenolic activity with low disease susceptibility was only observed in certain California cultivars, notably 'Ross' and 'Walgant', though the level of resistance was not promising. The association of high phenolics with susceptibility to flesh bruising and resistance of the fruit epidermis in 'Bolinha' material supports a pleiotropic effect for phenolics. No significant disease resistance role of PPO was identified in this test.

The lower average bruise severity for the Bolinha-OP relative to Bolinha-OP-hybrid genotypes is probably due to the absence of more mature fruit in the Bolinha-OP samples due to their very high green fruit drop. Evidence of a sampling bias is provided by the maturity distribution of Bolinha-OP-7 compared with 'Corona' 
(Fig. 1), where changes in tissue response are plotted relative to hue angle as an index of fruit maturity. Clingstone peach fruit at green-to-yellow color break have hue angles of $\approx 90^{\circ}$ to $95^{\circ}$, with subsequent decreasing angles representing changes in ground color through the yellow hues toward the full-ripe to over-ripe hues of yellow-orange $\left(\approx 60^{\circ}\right.$ to $\left.65^{\circ}\right)$. The scarcityof fully ripe fruit has shifted the population toward the immature stages where bruise damage is less severe and resistance higher. Comparable changes in bruise damage with freestone fruit ripening have been interpreted by Hung and Prussia (1989) to be the consequence of changes in flesh tissue integrity and elasticity. In Bolinha-OP-Hyb lines, strong selection against preharvest drop has allowed the inclusion of more mature fruit in these groups, leading to a higher overall bruise rating. Thus, the tests employed have probably underestimated both the phenolic levels as well as bruising and brown rot susceptibility of the original Bolinha-OP selections and to a lesser extent the Bolinha-OP-Hyb selections.

Similarly, the change in relative susceptibility of 'Corona' from 1990 to 1991 , appears to be partly the consequence of greater use of full-ripe to overripe fruit in the 1991 samples. Rot development in 'Corona', unlike in most cultivars tested, decreased in fully ripe to overripe fruit (Fig. 1). The more mature and so less susceptible 'Corona' fruit harvested in 1991 would have resulted in a lower population mean score.

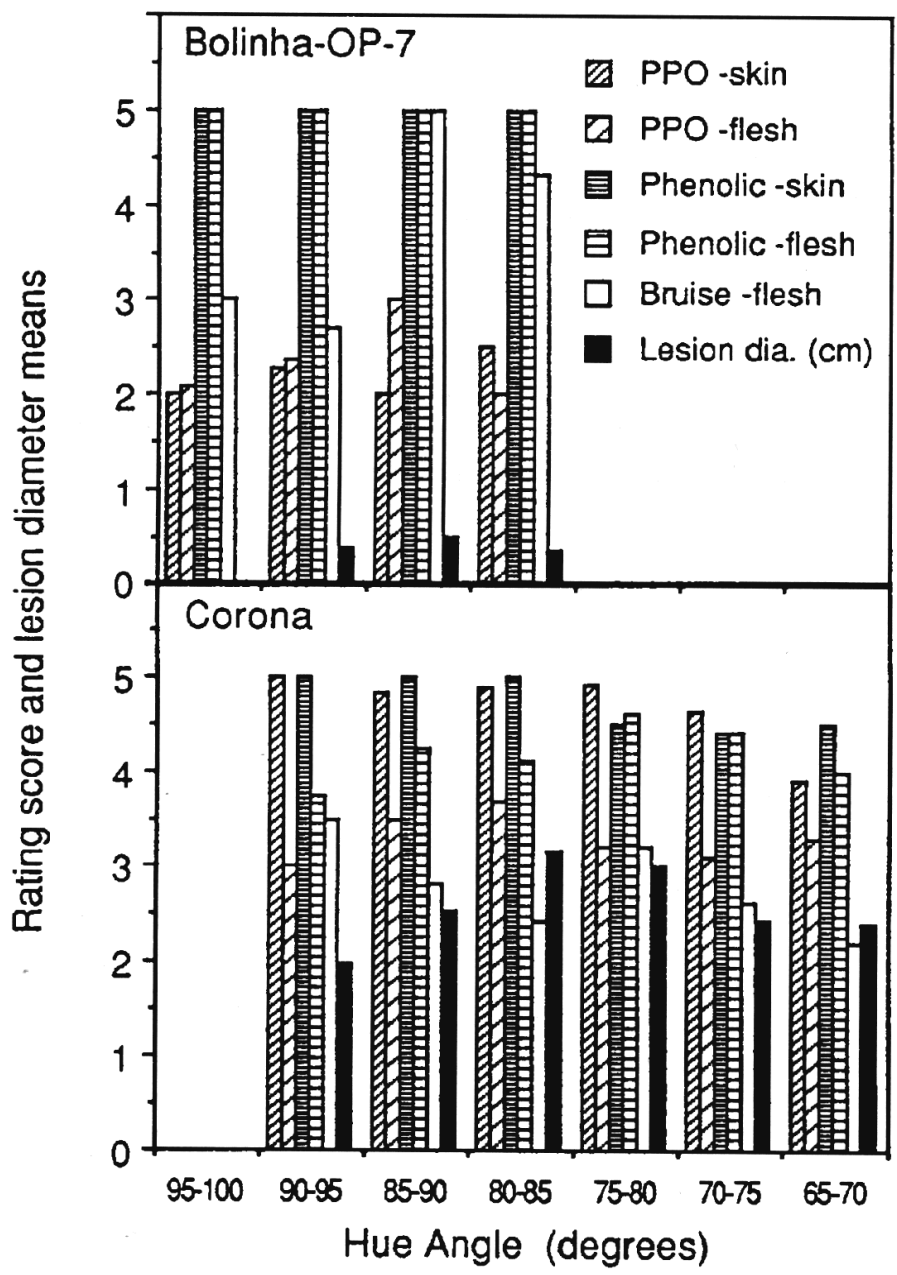

Fig. 1. Changes in phenolic content and polyphenol oxidase (PPO) activity in the skin (epidermis) and flesh, bruise severity ratings, and fruit rot lesion diameter at $72 \mathrm{~h}$ after inoculation, as related to changes in the hue angle of fruit ground color for two clingstone peach genotypes tested in 1991.

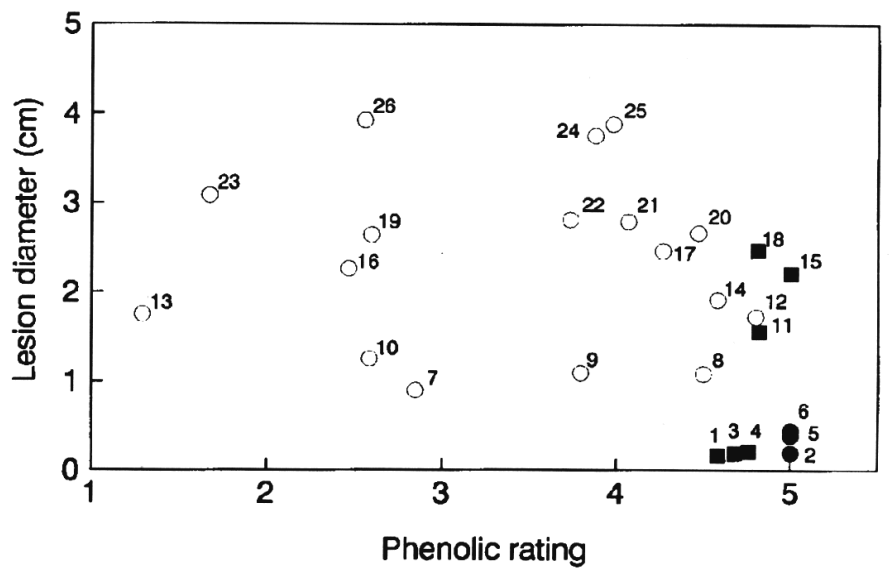

Fig. 2. Relationship between brown rot lesion diameter at $72 \mathrm{~h}$ after inoculation and ratings for phenolics among clingstone peach genotypes tested in 1991. (Numerals refer to reference numbers in Table 2. Bolinha-OP lines are shown as filled circles and Bolinha-OP hybrids shown as filled squares).

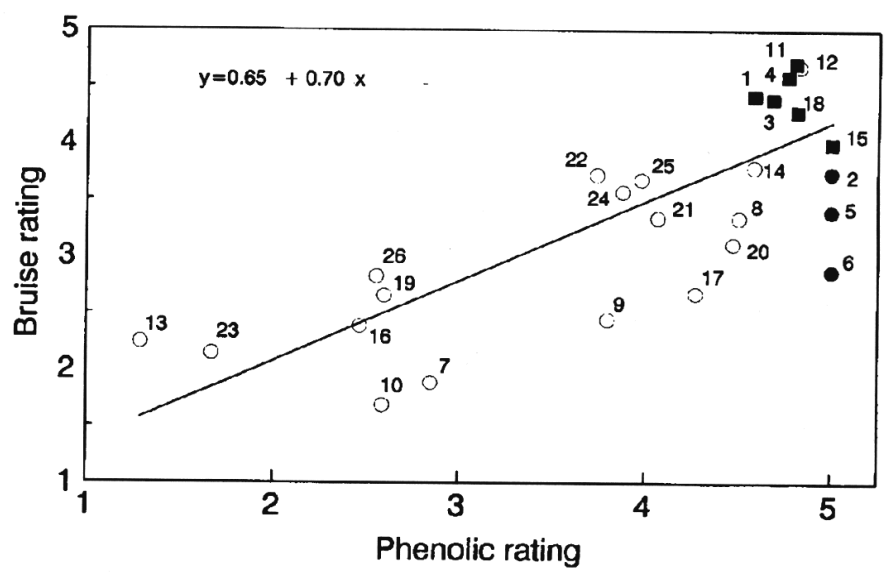

Fig. 3. Relationship between degree of discoloration following bruising and ratings for phenolics among clingstone peach genotypes tested in 1991. (Numerals refer to reference numbers in Table 2. Bolinha-OP lines are shown as filled circles with Bolinha-OP hybrids shown as filled squares).

As demonstrated in Fig. 1, disease resistance and biochemical performance can vary considerably depending on the degree of ripeness of the fruit. Accurate indices of maturity are, thus, essential to make objective comparisons between and within breeding lines. Ground color hue angle has been found to be one of the more reliable indicators of fruit ripeness for fresh market freestone peaches (Delwiche and Baumgardner, 1983; Meredith et al., 1989; Robertson et al., 1991). A greater efficacy of hue angle as a ripeness index might be expected for clingstone peach because carotenoids, which are the predominant ground color pigment, are more stable than the anthocyanins common in freestone peaches.

Previous work has identified physical barriers to fungal infection in the epidermis of 'Bolinha' derived material (Adaskeveg et al., 1989, 1991). Our study has identified high levels of phenolic activity in the epidermis and flesh. High phenolic levels and physical epidermal barriers, including thicker cuticle and more compact cell type, have been reported to be associated with fungal resistant in pecan [Carya illinoinensis (Wangenh.) K. Koch] by Wetztein and Sparks (1983). An important antifungal role of the high phenolic activity identified in the 'Bolinha' germplasm would greatly reduce its breeding value as high phenolic activity is causally correlated with high enzymatic browning. The specific role of phenolics in plant resistance to pathogenic fungi is not clear 
due to the numerous external and internal variables in such hostpathogen interactions (Manibhusaurao et al., 1988) as well as the wide array of biochemicals in fruits, ranging from cinnamic acid derivatives, flavans, and authocyanins to flavanols and condensed polyphenols that are broadly classified as phenolics (Van Buren, 1970). With improved knowledge of individual phenolic compounds, it may be possible to select for specific potent antifungal compounds having negligible contributions to enzymatic browning, provided these functions are not causally connected. The rapid assays employed in this work allow the large population screenings necessary for such au approach. Similarly, the ability to differentiate epidermis from flesh tissue may allow the development of processing peach lines in which antifungal compounds with undesirable effects on flesh quality are confined to the epidermal tissue, which is removed at processing.

\section{Literature Cited}

Adaskaveg, J.E., A.J. Feliciano, and J.M. Ogawa. 1989. Comparative studies of resistance in peach genotypes to Monilinia fructicola. Abs. \#387. Proc. Amer. Phytopathol. Soc. Annu. Meeting, 20 to 24 Aug. 1989, Richmond, Va. (Abstr.)

Adaskaveg, J.E., A.J. Feliciano, and J.M. Ogawa. 1991. Evaluation of the cuticle as a barrier to penetration by Monilinia fructicola. Phytopathology 81(10):1150. (Abstr.)

Aist, J.R. 1983. Structural responses as resistance mechanisms. In: J.A. Bailey and B.M. Deverall (eds.). The dynamics of host defense. Academic Press, New York.

Barkhausen, R. 1978. Ultrastructural changes in wounded plant storage cells, p. 1 to 42 In: G. Wahl (ed.). Biochemistry of wounded plant tissues. Walter de Gruyter, Berlin.

Byrde, R.J.W. and H.J. Willets. 1977. The brown rot fungi of fruit. Pergamon Press, New York.

Delwiche, M.J. and R.A. Baumgardner. 1983. Ground color measurements of peaches. J. Amer. Soc. Hort. Sci. 108:1012-1016.

Feliciano, A., A.J. Feliciano, and J.M. Ogawa. 1987. Monilinia fructicola resistance in peach cultivar Bolinha. Phytopathology 77:776-780.

Friend, J. 1985. Phenolic substances and plant disease, p. 367-392. In: C.F. Van Sumere and P.J. Lea (eds.). Annu. Proc. Phytochem. Sot. Europe. vol. 25. Clarendon Press, Oxford, England.

Gupta, Y. and J.L. Kaul. 1988. Alterations in phenolic metabolism of peach fruits infected with Monilinia laxa. Indian J. Mycol. Plant Pathol. 18:74-75.

Hall, R. 1971. Pathogenicity of Monilinia fructicola. I. Hydrolytic enzymes. Phytopathol. Z. 72:245-254.
Hung, Y.C. and S.E. Prussia. 1989. Effect of maturity and storage time on the bruise susceptibility of peaches (cv. Red Globe). J. Amer. Soc. Agr. Eng. 32(4):1377-1382.

Hunt, R.W.G. 1987. Measuring colour. Ellis Horwood, Chichester, UK. Kader, A. 1980. Brown discoloration of clingstone peaches. Cling Peach Quarterly. 16(1):12-13

Kader, A.A. and A. Chordas. 1984. Evaluating the browning potential of peaches. Calif. Agr. 38(3\&4):14-15.

Lakshminarayana, S., N.F. Sommer, V. Polito, and R.J. Fortlage. 1987. Development of resistance to infection by Botrytis cinerea and penicillium expansum in wounds of mature apple fruits. Phytopathology 77:1674-1678.

Lee, C.Y., V. Kagan, A.W. Jaworski, and S.K. Brown. 1990. Enzymatic browning in relation to phenolic compounds and polyphenoloxidase activity among various peach cultivars. J. Agr. Food Chem. 38:99-101.

Little, A. 1975. A research note on a tangent. J. Food Sci. 40:410-411.

Mace, M.E. 1963. Histochemical localizations of phenols in healthy and diseased banana roots. Physiol. Plant. 16:915-925.

Manibhushanrao, K., M. Zuber, and N. Matsuyama. 1988. Phenol metabolism and plant disease resistance. Acta Phytopathologica et Entomologica Hungarica. 23(1-2):103-114.

Meredith, F.I., J.A. Robertson, and R.J. Horvat. 1989. Changes in physical and chemical parameters associated with quality and postharvest ripening of harvested peaches. J. Agr. Food Chem. 37:1210-1214.

Ogawa, J.M., B.T. Manji, and R.M. Sonoda. 1985. Management of the brown rot disease on stone fruits and almonds in California, p. 8-5 In: T.J. Burr (ed.). Proc. brown rot of stone fruit workshop. New York State Agr. Expt. Sta., Geneva, New York.

Reeve, R.M. 1959. Histological and histochemical changes in developing and ripening peaches. I. The catechol tannins. Amer. J. Bot. 46:210.

Robertson, J.A., F.I. Meredith, and W.R. Forbus. 1991. Changes in quality characteristics during peach (cv. 'Majestic') maturation. J. Food Quality 14: 197-207.

SAS Institute. 1985. SAS/STAT guide for personal computers, version 6 ed., Joyner, S.P., ed.; SAS Institute, Cary, N.C.

Sztejnberg, A., H. Azaizia, and I. Chet. 1983. The possible role of phenolic compounds in resistance of horticultural crops to Dematophora necatrix hartig. Phytopath. Z. 107:318-326.

Van Buren, J. 1970. Fruit phenolics. p. 269-304 In: A.C. Hulme (ed.). The biochemistry of fruits and their products. Academic Press, New York.

Werner, D.J. and J.R. Ballington. 1982. Flesh browning of peach and nectarine cultivars. Fruit Var. J. 14:12-14.

Wetztein, H.Y. and D. Sparks. 1983. Anatomical indices of cultivar and age-related scab resistance and susceptibility in pecan leaves. J. Amer. Soc. Hort. Sci. 108:210-218. 